Locher, M. A. (2008). Relational work, politeness and identity construction. In Gerd Antos, Eija Ventola \& Tilo Weber (Eds.), Handbooks of Applied Linguistics. Volume 2: Interpersonal Communication (pp. 509-540). Berlin / New York: Mouton de Gruyter. DOI: 10.1515/9783110211399.4.509

\section{Relational work, politeness, and identity construction}

\author{
Miriam A. Locher ${ }^{1}$
}

\section{Introduction}

As social beings we express, communicate, and, ultimately, negotiate our identity through many different channels: one such channel may be the way we dress, another the way we comport ourselves; yet another important channel is the use of language. We can even claim that the way in which we use language plays a cru cial role when enhancing, maintaining, and challenging relationships in interpersonal communication. This use of language has variously been termed facework, sonal communication. This use of language has various (cf. Sections 3 and 4 for identity work, relational work or rapport management (this use by utilizing some of the references). This chapter is intended to explain this use by utilizing some of the literature on identity that follows a postmodernist understanding of the concept 586). In addition, an attempt is made to combine research on the construction of 586). In addition, an attempt is made to combine research on the construction of developed ideas under the keyword politeness. It is shown in this chapter that politeness research can fruitfully be combined with research on identity construction. This line of thought has already been pursued to some extent in the field of gender research (cf. Swann 2000), ${ }^{2}$ and also in studies on face and identity more generally (cf. Tracy 1990; Spencer-Oatey 2007a,b). The chapter thus focuses on the interpersonal side of communication and further intends to explore the links between identity, face, and politeness. It is organized as follows: In Section 2, I will discuss the interpersonal and the informational aspect of language. In Section 3 I will move on to link these ideas to identity construction in general. In Section 4 different approaches to politeness will be at the heart of the investigation and will be discussed with identity construction in mind. In Section 5 , concluding remarks on the two approaches to interpersonal communication will round off the chapter.

\section{The interpersonal and the informational aspect of language}

When engaging in linguistic interaction, people never just exchange factual information but also always reveal information about themselves and their perception of roles in a particular context. The choice of language in different speech situations, in other words, the "register" or "style" the interactants use to accommodate to their addressees and the speech situation, thus always entails 
interpersonal information, too. The mere fact that individuals have different registers and styles at their disposal and make use of them can be seen as evidence for this need to negotiate roles in interaction.

In the literature, the relationship between the informational and the interpersonal side of communication has been discussed in numerous studies. Watzlawick, Beavin, and Jackson (1967: 54), for example, maintain that "[e]very communication has a content and a relationship aspect such that the latter classifies the former and is therefore a metacommunication." These two parts ${ }^{4}$ cannot be disconnected from each other. There are, however, discourses that focus more on the content aspect, such as news broadcasts, or on the relationship aspects, such as rounds of gossip. Kasper (1990:205) names the former type of interaction transactional discourse, in the sense that these exchanges focus on "optimally efficient transmission of information", and the latter interactional dis course, in that it "has as its primary goal the establishment and maintenance of social relationships". However, the two types of discourse can never be entirely separated from one another (Fill 1990).

\section{Relational work: Language and identity construction}

Having generally postulated that there is a content and a relational aspect to acts of communication, we can easily link these ideas to identity construction. In Locher (2004) and Locher and Watts (2005), we have called "the process of defining relationships in interaction" relational work. This term is meant to highlight the fact that interlocutors invest "work" into their ways of communicating by adapting their language to different speech events and to the different goals that they might be pursuing. In addition, the term points to the relational aspect of communication in that it highlights the relations the interlocutors have with each other. It is important to stress that the term relational work does not only refer to polite linguistic behavior, but is meant to cover the entire spectrum of interpersonal linguistic behavior. ${ }^{5}$ Polite, refined, and polished language might do a great deal for a person's identity construction, but so does rude, impolite, and aggressive language (cf. also Locher and Bousfield (2008) and Locher and Watts (2008) on linguistic impoliteness).

The construction of identity through linguistic means has been the subject of study in numerous fields. For an excellent and detailed overview of different approaches, I refer the reader to a critical appraisal by Mendoza-Denton (2002). Her general definition of the term is as follows:

[Identity is] the active negotiation of an individual's relationship with larger social constructs, in so far as this negotiation is signaled through language and other semiotic means. Identity, then, is neither attribute nor possession, but an individual and collective-level process of semiosis. (Mendoza-Denton 2002:475)
This definition can nicely be tied up with the notion of relational work: relational work refers to the ways in which the construction of identity is achieved in interaction, while identity refers to the "product" of these linguistic and non-linguistic processes. The definition of identity adopted in this chapter is thus one that could be called postmodernist (Swann 2000: 43) in that it sees identity as in flux and not as fixed (cf., e.g., Davies and Harré 1990; Schiffrin 1996; Adelswärd and Nilholm 2000; De Fina 2003; Joseph 2004; Locher 2006a; Locher and Hoffmann 2006)

To exemplify this line of reasoning, I will briefly focus on the issue of language and gender. Gender is one aspect of a person's identity that has been studied extensively. Work in this research field also shows how our understanding of identity construction has developed over time. Quite dramatic shifts in focus have taken place from the 1970s until today (Swann 2000, 2002; Bucholtz 2004). According to Bucholtz (2004), we can identify several movements within gender studies. In the 1970s and 1980s, the early feminists were concerned with sexism, misogyny, and the social inequality between men and women, as well as the exercise of power more generally. As an example, Bucholtz discusses the use of generic he and feminist attempts to introduce new, non-gendered pronouns to avoid sexism in language.

The next phase in gender research can be labeled the difference and dominance approaches. The dominance approach suggested that men and woman use language differently and that these different styles allow men to exercise power over women. The difference approach was characterized by "a recognition and even celebration of women's own practices" (Bucholtz 2004: 415) and by the claim that women form a different cultural group from men. The studies following this line of thought, however, often remained on a very general level and could be reproached for excluding those men and women who did not fit the general middle-class, heterosexual profile from which most data were derived (Bucholtz 2004: 417). This resulted in more efforts to research gay and lesbian linguistic behavior as well as in studies on non-white and non-middle class speech communities.

Bucholtz ends her review of the literature on gender with a discussion of approaches that focus on "identity in practice and performance". She claims that

$[\ldots$ s]tudies of women of color and of lesbians and gay men have shown the import ance of moving away from broad, even universal, categories like gender as the sole explanation for speech patterns and toward other dimensions of identity that enrich and complicate language and gender analyses (Bucholtz 2004: 422).

Bucholtz raises an important issue in this quotation: we have to be aware of the danger of deriving from the variable we are studying (for example gender, but also any of the other sociological variables such as age or class) a monocausal explanation for observed linguistic patterns (cf. Swann 2000, 2002). ${ }^{6}$ Bucholtz ultimately puts the emphasis on agency, which results in a definition of gender 
and identity more generally "as achieved and fluid" (Bucholtz 2004: 422, author's emphasis), rather than being predetermined by social categories.

In Bucholtz and Hall (2005: 586), the authors address the study of identity, "the social positioning of self and other", more generally by reviewing the existing literature in the various fields of study. This framework provides the best current guideline for the study of identity construction. They synthesize the ideas on identity and propose a framework in which this concept should be studied by taking the following five principles into account: the emergence principle, the positionality principle, the indexicality principle, the relationality principle, and the partialness principle. I will introduce each of these in turn.

The emergence principle is defined as follows:

1. Identity is best viewed as the emergent product rather than the pre-existing source of linguistic and other semiotic practices and therefore as fundamentally a social and cultural phenomenon (Bucholtz and Hall 2005: 588).

This principle highlights the emergent and the relational aspect of identity construction. By pointing out that identity is a product of interaction, the authors avoid the previously mentioned danger of imposing preexisting categories (such as, e.g., gender, age, class) on the text as the only explanatory factors and high" light the social and cultural bases of identity.

The second principle is the positionality principle:

2. Identities encompass (a) macro-level demographic categories; (b) local, ethnographically specific cultural positions; and (c) temporary and interactionally specific stances and participant roles (Bucholtz and Hall 2005: 592).

Essentially, this highlights that (a) identity, while being constructed relationally, is also the product of a combination of different dimensions, among them the previously mentioned influence of age, class, and sex. In addition, there are (b) factors that can only be discerned when ethrographic work uncovers the meaning of linguistic strategies for the members of a particular social practice, and finally, (c) the authors point out that the emergent participant roles (e.g., evaluator, joke teller, or engaged listener) in an ongoing interaction contribute to identity construction.

The third principle is called the indexicality principle. It posits that the interactants' identities are the product of several processes of indexing through language, and thus refers to the actual linguistic mechanisms the interactants use. Bucholtz and Hall (2005: 594) claim that "these processes occur at all levels of linguistic structure and use." Examples are

(a) overt mention of identity categories and labels; (b) implicatures and presuppositions regarding one's own or others' identity position; (c) displayed evaluative and epistemic orientations to ongoing talk, as well as interactional footings and participant roles; and (d) the use of linguistic structures and systems that are ideologically associated with specific personas and groups (Bucholtz and Hall 2005: 594).
The relationality principle entails the crucial point that

[...] identities are never autonomous or independent but always acquire social meaning in relation to other available identity positions and other social actors (Bucholtz and Hall 2005: 598).

This principle works on many different levels. One of these relations refers to processes in which similarities with or differences from other perceived groups are constructed by social actors. A further relation is found between genuineness and artifice. This relation refers to the social process that negotiates "what sorts of language and language users count as 'genuine' for a given purpose" (Bucholtz and Hall 2005: 601) and what is constructed as "crafted, fragmented, problematic or false" (602). The third relation discussed in Bucholtz and Hall (2005: 603) refers to "structural and institutional aspects of identity formation." The notions of authority, hegemony, and power relations more generally are at play here, in that identities are authorized or dismissed by these structures.

The final aspect of the identity framework proposed by Bucholtz and Hall (2005) is the partialness principle. It states that

[a]ny given construction of identity may be in part deliberate and intentional, in part habitual and hence often less than fully conscious, in part an outcome of interactional negotiation and contestation, in part an outcome of others' perceptions and representations, and in part an effect of larger ideological processes and material structures that may become relevant to interaction. It is therefore constantiy shifting both as interaction unfolds and across discourse contexts (Bucholtz and Hall 2005: 606).

The authors stress that agency in identity construction should not be understood as a fully rational and always conscious process since there are undoubtedly aspects that are habitual. In addition, identity construction is a composite of processes. Notice the use of "in part" in the quotation above, which points both to the compositionality of identity as well as to the fact that, "[b]ecause identity is inherently relational, it will always be partial, produced through contextually situated and ideologically informed configurations of self and other" (Bucholtz and Hall 2005: 605).

From this brief introduction to the study of identity as proposed by Bucholtz and Hall, we can glimpse how intricate and dynamic such processes of identity construction are. In the next section, the links between research on politeness and identity will be discussed.

\section{Relational work and politeness issues}

Politeness research is one of the productive research strands that aims at a better understanding of how interactants negotiate the interpersonal side of communication. It is for this reason that different approaches are reviewed here with re- 
spect to relational work in general. It is, of course, impossible to give a comprehensive overview of this field here. For such introductions, I refer the reader to the works of Eelen (2001), Watts (2003), and Locher (2004). Two influential works that have appeared during the past few decades will be introduced in this chapter. They are Brown and Levinson's $(1978,1987)$ concept of face-saving and Leech's (1983) politeness principle. This is followed by a summary of approaches that highlight social norms and the evaluative character of judgments on linguistic behavior (Watts 2003; Locher 2004; Locher and Watts 2005). Since the notion of face is discussed in all of these approaches, the next section is dedicated to explaining this important concept.

\subsection{The notion of face}

Goffman's (1967) notion of face, ${ }^{7}$ which he derived from Durkheim (1915), is an important concept for the discussion of identity construction and relational work in general. Goffman (1967) defines face as follows:

The tern face may be defined as the positive social value a person effectively claims for himself by the line others assume he has taken during a particular contact. Face is an image of self delineated in terms of approved social attributes - albeit an image that others may share, as when a person makes a good showing for his profession or religion by making a good showing for himself (Goffman 1967:5).

In Locher (2004: 52), I suggested that face can be equated with a mask, ${ }^{8}$ an image a person gives him- or herself during a particular interaction, and that this face is not fixed but negotiated in emergent networks. The notion of emergent network is taken from Watts (1991). He makes a distinction between latent networks and emergent networks. Latent networks comprise the links between social interactants that have been previously established. The emergent network refers to the actual moment in time when interactants engage in a social practice and activate and renegotiate these links (for a discussion, see Locher 2004: 27-30). The recurring negotiation of face in emergent networks implies that a person can have several different faces or masks, depending on the situation. In addition, it is crucial that face depends on the acceptance of others. Goffman (1967: 10) describes this by saying that "it is only on loan to [an individual] from society". Finally, Goffman (1967: 13) maintains that considerations of face will influence interactions between people.

Since this understanding of face implies that interactants always have face, even though the face put on might differ from situation to situation, this means that there is no face-less communication (cf. Tracy 1990: 221; Scollon and ScolIon 2001: 48), just as there cannot be any communication without an interpersonal aspect to it. The notions of face and mask can be linked to an interactant's understanding of a particular identity that he or she wishes to propose in a par- ticular situation. It is this link that allows us to connect politeness research with research on identity construction within a framework of the study of relational work, as long as we do not perceive face to be a fixed construct. ${ }^{9}$ On the contrary, we should conceptualize it as a product, emerging in interaction. This is in line with Bucholtz and Hall's (2005: 587) claim that identity "is intersubjectively rather than individually produced and interactionally emergent rather than assigned in an a priori fashion." It also supports Tracy's (1990) position that

Face is a social phenomenon; it comes into being when one person comes into the presence of another; it is created through the communicative moves of interactants. Whereas face references the socially situated identities people claim or attribute to others, facework ${ }^{[10]}$ references the communicative strategies that are the enactment, support, or challenge of those situated identities (Tracy 1990:210).

It has to be stressed that the notion of face proposed here is not the same in all the politeness frameworks discussed below. Brown and Levinson (1987) have a more static, bipartite view of face, as explained in Section 4.2, while Spencer-Oatey (2005) uses a more flexible, but also bipartite definition of face in her framework of rapport management, as discussed in Section 4.5." However, it is suggested that the notion of face can stand for identity construction in more general terms and can be useful for both politeness and identity research in this sense.

\subsection{Brown and Levinson's approach to politeness}

Without any doubt, Brown and Levinson (1978/1987) have written the most influential work on politeness in the last few decades. Their work has been enthusiastically received, reproduced, and developed further by many scholars, but has also been extensively criticized by others. ${ }^{12}$ In what follows, I will highlight how their study has furthered our understanding of relational work, politeness, and identity construction in general. To do this, I will briefly introduce their main ideas.

Two key terms in Brown and Levinson's framework are face and the facethreatening act. Face in a Goffmanian sense has already been introduced above. Brown and Levinson (1987:61) define face as "the public self-image that every member wants to claim for himself". They also maintain that it is made up of two dualistic wants. They introduce the terms positive face and negative face:

negative face: the want of every "competent adult member" that his actions be unimpeded by others.

positive face: the want of every member that his wants be desirable to at least some others (Brown and Levinson 1987; 62).

These two sides have also been called the independence and involvement aspects of face by other researchers (Scollon and Scollon 2001: 48). Brown and Levinson (1987: 62) argue that "face respect is not an unequivocal right", which 
means that an interactant's face is vulnerable. The authors believe, however, that it is in both the speaker's and the addressee's interest to "maintain each other's face" (1987:60). This is complicated by the fact that there are acts which intrinsically threaten one or both aspects of an individual's face. These acts are called face-threatening acts (FTAs). Brown and Levinson make the following proposition:

Unless S's want to do an FTA with maximum efficiency [...] is greater than S's want to preserve H's (or S's) face to any degree, then $S$ will want to minimize the face threat of the FTA (Brown and Levinson 1987: 62).

The key here is the minimization of the face threat. The authors claim that politeness plays a role as soon as speakers consider each others' face and wish to minimize FTAs. To achieve this minimization, the speakers have several strategies at their disposal, which are mutually known to both speaker and addressee. These strategies range from not committing the FTA at all (strategy 5 in Figure 1) to committing the FTA without mitigation (strategy 1), with intermediate stages that are characterized by making use of different types of redressive means (strategies 2 to 4 ).

Circumstances determining choice of strategy:

Lesser

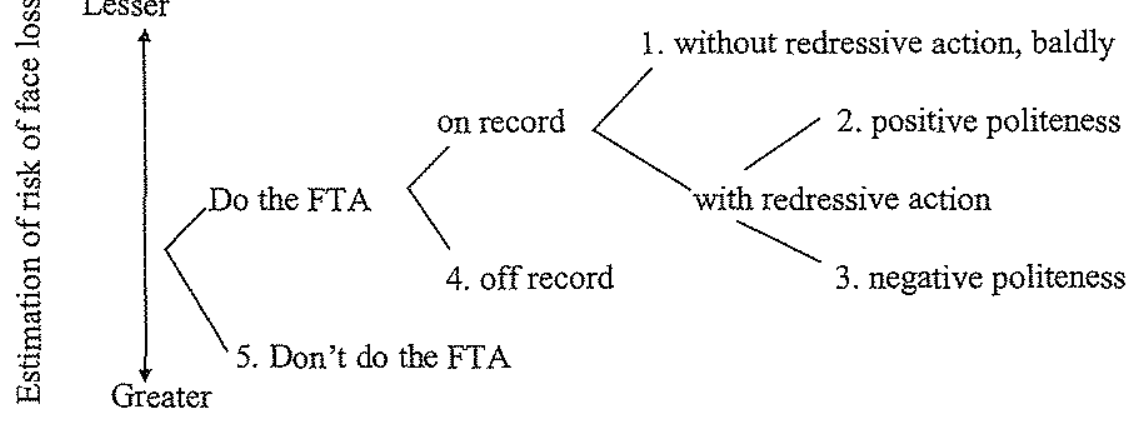

Figure 1. Possible strategies for realizing FTAs (Brown and Levinson 1987: 60)

The speaker's choice of a strategy depends on several factors that together establish the estimated risk of loss of face, or the "weightiness" of the FTA " $x$ " $\left(W_{x}\right)$. These factors are the value of the distance (D) between the speaker (S) and the hearer $(\mathrm{H})$, the measure of the power that the hearer has over the speaker $(\mathrm{P})$, and the relative ranking of the imposition in its cultural and situational context $\left(R_{x}\right)$. This equation is summarized as follows: $W_{x}=D(S, H)+P(H, S)+R_{x}$ (1987:76). It is best understood as an abstract way of representing the intricate social factors that play a role in interaction.
What does this type of politeness research have to do with relational work and identity construction? An important aspect of identity construction is whether or not we want to project an image of ourselves as someone who is aware of the social norms of behavior that are relevant in a particular social practice. One way of displaying such knowledge is by selecting the type of relational work that is suitable for redressing face-threatening acts in a specific context. Consider, for example, the question of address terms (cf. Brown and Gilman 1960). Anybody who has a language such as French or German as his or her mother tongue knows that there is a difference between the uses of the personal pronouns $t u$ and vous or Du and Sie. It is important to pick the right pronouns when addressing an interlocutor since these pronouns index intimacy and distance, as well as hierarchical relationships. It is, in other words, facethreatening to pick a pronoun that is too close $(t u / D u)$ or one that is too distant (vous/Sie) since this could imply that the relationship between the interlocutors is not as expected.

While one could say that English does not have this problem (since you refers to both forms), the English situation is nevertheless far from straightforward. There is an intricate negotiation between calling each other by a nickname (Bill), first name (William), using a combination of address form and last name (Mr. Clinton), or even professional titles combined with last names (President Clinton). What combination is used depends on many different factors such as whether the two interactants are related, whether they are friends, whether they are close or distant, whether their relationship is work-related or not, whether they are on the same hierarchical level, etc. Knowledge about which of the address types is appropriate in which context is acquired by socialization into the different social practices.

The fact that we are dealing with face issues can be exemplified by a brief anecdote. Two exchange students from the United States, ${ }^{13}$ who participated in our program in the English Department in Berne, Switzerland, addressed the teaching staff with their title $(D r)$ and seemed not to mind when the teaching staff addressed them by first name. It is, however, customary among the linguists in this department to use only first names to address each other and the students, and to expect the same from the students when addressing staff members. The American students felt uncomfortable adjusting to this custom (even after having been told that it is okay to call their teachers by their first names), and it took them some time to adopt it. What is interesting is that a public usage of "Dr. Locher" in class, such as in a question, always causes raised eyebrows from their fellow Swiss students. To address somebody in a formal way, in a situation where the custom calls for informal usage, thus, reflects on the speaker as well as on the addressee. While the American students wanted to use a respectful term of address, they may have come across as too deferential in the eyes of their peers. It is, of course, also possible to display that one knows 
the norms and conventions of a particular social interaction and to subvert them. A student might use the term "Dr. Locher" in the context above to question my expertise rather than to confirm it and to show respect.

Recognizing that politeness issues play a role in identity construction, we must acknowledge that some aspects of Brown and Levinson's work are problematic from the perspective that sees identity as being in flux rather than fixed. On the one hand, the notion of face, described as consisting of two wants, is too static to equal face with identity. I suggest that it is preferable to return to the original Goffmanian sense of the term which makes a link between the two concepts possible. The variables $\mathrm{P}, \mathrm{D}$, and $\mathrm{R}_{x}$ can be seen as too simple an explanation for the intricate social processes that take place when interactants engage in social practice and position self and other. There is also a problem with assigning linguistic form to function, as indicated in the linguistic strategies which link linguistic indirectness with the level of politeness, a position that is no longer pursued in many of the more recent works on politeness. Finally, the term politeness may actually be a misnomer since Brown and Levinson describe mitigating relational work more generally, without being concerned about whether or not the social agents themselves consider the interaction polite or not. The last two points will be taken up again in Section 4.4. Having said this, Brown and Levinson's work offers us the description of an abundance of linguistic strategies (cf. the indexicality principle introduced in Section 3) that can be identified in social interaction and that can be exploited to discuss the construction of identity in emergent networks.

\subsection{Leech's politeness principle}

Leech (1983) deals with politeness in connection with his work on principles of pragmatics in general. His starting point is Grice's (1975) cooperative principle, which is expressed in the following four maxims:

\section{Quantity i) Make your contribution as informative as is required} (for the current purposes of the exchange).

ii) Do not make your contribution more informative than is required.

2. Quality i) Do not say what you believe to be false.

ii) Do not say that for which you lack adequate evidence.

3. Relation i) Be relevant.

4. Manner i) Avoid obscurity of expression.

ii) Avoid ambiguity.

iii) Be brief (avoid unnecessary prolixity).

iv) Be orderly.

(Grice 1975: 45-46)
When interactants do not follow one or more of these maxims, they create socalled implicatures, i.e., they create additional meaning. ${ }^{14}$ Leech argues that what he calls the politeness principle explains the motivation for many of these implicatures. He proposes that the aim of the politeness principle is "to maintain the social equilibrium and the friendly relations which enable us to assume that our interlocutors are being cooperative in the first place" (Leech 1983: 82). For example, an interlocutor might interpret a roundabout way of formulating a request, which constitutes a deviation from the maxim of quantity and the maxim of manner, as being motivated by the speaker's wish not to impose on the addressee. In Leech's understanding, the indirect linguistic realization of the request, which constitutes a departure from the cooperative principle, is motivated by the speaker's wish to appear polite. More generally, we are once more dealing with the positioning of self and other in social practices.

Leech (1983) formulates his politeness principle in the form of the following maxims:

(I) TACT MAXIM (in impositives and commissives)

(a) Minimize cost to other

[(b) Maximize benefit to other]

(II) GENEROSITY MAXIM (in impositives and commissives)

(a) Minimize benefit to self

[(b) Maximize cost to self]

(III) APPROBATION MAXIM (in expressives and assertives)

(a) Minimize dispraise of other

[(b) Maximize praise of other]

(IV) MODESTY MAXIM (in expressives and assertives)

(a) Minimize praise of self

[(b) Maximize dispraise of self]

(v) AGREEMENT MAXIM (in assertives)

(a) Minimize disagreement between self. and other

[(b) Maximize agreement between self and other]

(VI) SYMPATHY MAXIM (in assertives)

(a) Minimize antipathy between self and other

[(b) Maximize sympathy between self and other] (Leech 1983: 132)

In general, Leech (1983: 133) claims that interactants give "avoidance of discord" more importance than "seeking concord". He also points out that not all the maxims are equally important. The Tact Maxim and the Approbation Maxim are considered to be stronger than the Generosity and Modesty Maxims. As an explanation, Leech maintains that politeness is generally more oriented towards the other than the self.

While Brown and Levinson (1987) remain at a very abstract level when they give us their politeness equation $\left(W_{x}=D(S, H)+P(H, S)+R_{x}\right)$, Leech focuses 
more explicitly on the formulation of the "norms" that influence the calculation of the relative ranking of the imposition of the face-threatening act $\left(R_{x}\right)$. It is, however, doubtful whether maxims formulated in this manner are also suitable to capture politeness universally (O'Driscoll 1996: 29). Leech's maxims become more convincing once we argue that they describe culture-specific notions of politeness rather than universal ones. In other words, it may well be that people taking part in a social practice in Britain orient towards these norms both when they are in the role of speakers and of addressees. In analogy, it may well be that other cultures will give more or less importance to some of Leech's proposed maxims, or it may be that they have entirely different ones that constitute polite behavior (cf. Spencer-Oatey 2000: 40; Locher 2004: 66)

With respect to identity construction and relational work, we can say that norns of behavior are clearly at the heart of the issue. The anecdote of the adequate use of address terms in the previous section has given evidence for this. Leech has to be given credit for highlighting this fact even more explicitly than Brown and Levinson did before him.

\subsection{The discursive approach to politeness}

Building on and sometimes departing from what Brown and Levinson (1978/ 1987) and Leech (1983) have proposed, many other researchers have developed other ideas on politeness (cf., among others, Fraser 1990; Kasper 1990; Holmes 1995; Held 1995). In what follows, however, I will focus on a more recent approach that highlights the discursive notion of the concept of politeness as such (Watts 2003; Locher 2004; Locher and Watts 2005, 2008) and claims that politeness is a comment on relational work in particular social practices or communities of practice ${ }^{15}$ (cf., e.g., Watts 2003; Mills 2003, 2004, 2005; Mullany 2004, 2008; Schnurr, Marra, and Holmes 2007, 2008; Graham 2007, 2008).

In Locher $(2004,2006 \mathrm{~b})$ and in Locher and Watts $(2005,2008)$, the claim is made that what Brown and Levinson have studied should not be seen as politeness per se, but as the description of linguistic strategies to mitigate facethreatening acts within the more general framework of relational work or identity construction. This means that we make a distinction between the term politeness, as used in a theory such as Brown and Levinson's, and the understanding of what politeness may mean for a lay person. This difference has been called the distinction between first order (lay) and second order (theoretical) conceptions (cf. Watts, Ehlich, and Ide 1992; Eelen 2001; Watts 2005).

This distinction makes it possible to describe the face-threatening character of a linguistic act and to point to the linguistic strategy of mitigation used with the help of Brown and Levinson's framework without a priori saying anything about the level of politeness witnessed. Consider, for example, the following well-known constructed sentences that might be uttered during a lunch conversation:

(1) (a) Pass me the salt.

(b) Could you please pass me the salt?

(c) Would you be so kind as to pass me the salt?

Depending on the context and the way in which these sentences are uttered, any of them might be appropriate and any might be inappropriate. If you are very close to each other and you generally talk on a very informal basis, an example such as (1a) might be called for, while (1c) might be over the top or even downright insulting. If you are on different hierarchical levels and if you usually talk to each other in a very formal way, you might go for (1c) and find (1a) out of place. The point here is that we cannot easily equate linguistic indirectness with linguistic politeness, or, more generally, linguistic form with linguistic function. On the contrary, we have to be very careful in taking into account the context of the linguistic utterance and any evidence from the interactants themselves that they may have wanted to use relational work in a particular way. For this reason, it is crucial to study the norms of the particular social practice in question. This is in line with Bucholtz and Hall's (2005) positionality principle, as explained in Section 3.

It is clear that a concept such as politeness has an evaluative character and is thus linked to social norms which are negotiated by social beings in interaction over time. This is what is meant by the discursive nature of politeness. This approach highlights the importance of social norms even more than Leech's (1983). The difference is that we do not claim to be able to generally state the norms in question in the form of maxims, but we rather wish to stress that the norms as such are constantly in flux and are created, maintained, challenged, and ultimately changed by participants in social practices over time.

By using the term politeness again in its lay meaning, we can free it from the overgeneralization that came with its use as a theoretical concept. We claim that polite linguistic behavior is actually only one very small aspect of relational work, namely relational work that is judged by participants in situ as appropriate and positively evaluated or marked according to the norms of a social practice (cf. Watts 1989, 1992; Locher 2004, 2006b; Locher and Watts 2005, 2008). The notion of frame, i.e., "structures of expectation based on past experience" (Tannen 1993: 53), explains the basis on which these judgments are made. A frame is acquired over time in social practice when interactants categorize the experiences of similar past situations, or draw conclusions from other people's experiences. A frame can contain expectations about action sequences (such as money transactions in a sales situation), but also about role and identity issues (such as the roles of sales assistant and customer). In Locher and Watts 
(2008: 78), we point out that "[t]he theoretical basis of 'frames' are cognitive conceptualisations of forms of appropriate and inappropriate behaviour that individuals have constructed through their own histories of social practice." Once again, it is important to stress that these norms and expectations are acquired over time and are constantly subject to change. When discussing the emergence principle in relation to identity construction, Bucholtz and Hall (2005) state tha

the property of emergence does not exclude the possibility that resources for identity work in any given interaction may derive from resources developed in earlier interactions (that is, they may draw on 'structure' - such as ideology, the linguistic system, or the relation between the two) (Bucholtz and Hall 2005: 588).

Hence people do not start inventing norms and expectations from scratch every time they meet. On the contrary, the discursive understanding of impoliteness and politeness issues stresses the importance of communities of practice and frames, which means that people draw on their experience and that these concepts entail historicity.

As a consequence of this historicity, as well as the discursive nature of the evaluative notion of politeness, we can say that it is possible that members of different social practices may perceive not only different linguistic behavior as polite, but may also construct the lexeme 'politeness' as having slightly different connotations. The meaning of politeness has clearly shifted over time. The Oxford English Dictionary (OED) reports "intellectual refinement; polish, elegance, good taste" as obsolete meanings for politeness with quotations from the $17^{\text {th }}$ century. Stein $(1994: 8)$ claims that before the $18^{\text {th }}$ century, politeness referred to "a social ideal, the polite urban, metropolitan gentleman, well-versed in the art of "polite' conversation, a man about town". By the second half of the $18^{\text {th }}$ century, a new notion of politeness had developed, one that is closely linked to prescriptivism, in that two poles between "correct" (polite) and "incorrect" (impolite) language usage were established and described, for example, in the prescriptive grammars of the time. ${ }^{16}$ The modern definition of politeness given in the OED is "[c]ourtesy, good manners, behaviour that is respectful or considerate of others". The entries for the meaning of the adjective polite in the OED read as follows:

1. a. Smoothed, polished, burnished. Obs.

b. Clean; neat, orderly. Obs.

2. a. Of language, the arts, or other intellectual pursuits: refined, elegant, scholarly; exhibiting good or restrained taste.

b. Of a person, social group, etc.: refined; cultured, cultivated; (also) wellregulated. Now chiefly in polite society, circles, etc.

c. Courteous, behaving in a manner that is respectful or considerate of others; well-mannered.
It would be premature, however, to claim that there is general agreement about the exact connotations of the terms polite and politeness in all the different social practices (cf. Mills 2002, 2004). It is even possible to argue that the term politeness carries negative connotations for some groups of people. This is the case when they consider what others might perceive as socially appropriate behavior as being inappropriate to a certain extent according to their own norms. In Locher and Watts (2008) we suggest that

this might lead to latently negative evaluative lexemes such as standoffish, stuck-up, hoity-toity, etc., thus indicating that an individual who expresses such an evaluation is aware that others would consider the behavior as appropriate, but personally interprets it negatively (Locher and Watts 2008: 98).

Clearly further research is needed to establish the connotations that the lexemes mentioned carry today for different groups of people.

Another advantage of investigating politeness as a first order concept is that we do not perceive its opposite to be impoliteness in general, but allow for the possibility that relational work which is negatively evaluated as breaching social norms may be judged in many different ways by participants in a social practice. The literature on impoliteness is still scarce in comparison to the voluminous literature on politeness. Early approaches took impoliteness as a mirror phenomenon to politeness, often based on an approach similar to Brown and Levinson's (cf., e.g., Lachenicht 1980; Culpeper 1996; Kienpointner 1997). The more recent literature is more diverse both in its methodological approaches as well as in its understanding of impoliteness (cf., e.g., Culpeper, Bousfield, and Wichmann 2003; Culpeper 2005; Bousfield and Locher 2008). The need to steer away from a simple dichotomy between polite and impolite behavior, however, is clearly recognized, and more research is encouraged to study behavior that is face-aggravating in particular social practices.

Let us look at an example in which a metacomment on relational work is being made that was perceived as negative. In (2), taken from Baumann et al. (2006), who studied impoliteness in a small number of family interactions in Switzerland, the metacomment unhoflech ('impolite') is mentioned by one of the participants. The conversation took place during a family dinner and was documented immediately after the interaction. The participants are a father and mother, their son, and their daughter, who are in their early twenties. The language is Bernese, the Swiss German dialect spoken by the participants, and is glossed with an idiomatic English translation. ${ }^{17}$ The mother asks her son why his girlfriend Rahel, who had left the house only five minutes before the meal, does not have dinner with the family. 
(2) 1 Mother: Wisso isst de ize d Rahel nid mit üs?

'So how come Rahel doesn't eat with us?'

2 Son: Si het doch gseit si wott nid --

'But she said that she didn't want to --'

3 Mother: Nei, das hesch du gseit. D Rahel hät nämlech wöue, i has ire agseh.

'No, it was you who said that. Rahel in fact wanted to, I saw it.'

4 Son: Dashesch du äuä sicher nid.

'No you surely didn't.'

5 Mother: (gets louder) Weisch, si möchte üs vilich ou kennelehre. Sie würd nie eso blöd tue, du tuesch eso blöd.

'You know, she might want to get to know us, too. She would never act this stupidly, you are the one who acts stupidly.'

6 Son: (gets louder as well) Tue doch nid eso, hey, ig ma ize nid mit dir über das rede.

'Stop acting like this. Hey, I don't want to talk about this with you now.'

7 Mother: (even louder) Ig finge eifach we si jedes Wuchenänd hie ver bringt und sich die ganzi Zit vor ïs versteckt isch das e chli unhöflech - -

'All I'm saying is that, if she stays with us every weekend and hides from us the whole time, then this is somewhat impolite--'

8 Father: (very loud) Chöit dir ize über öppis angers rede bitte, es cha doch nid si, dass dir bi jedem znacht schtïrmet.

'Could you now talk about something else, please. How can you always be fighting during dinner.'

9 Mother: (aggressive) Ach ize wosch du üs scho vorschribe über was mir söue rede.

'Ahh now you even want to tell us what we're supposed to talk about.'

10 Son: (to father) Misch di nid i!

'Mind your own business.'

11 Mother: (to father) Für wän hautisch di eigentlech?

'Who do you think you are anyway?'

12 Daughter: Er isch der Herrgott.

'He's God.'

13 Father: (in a rather joking way) I bi schliesslech z Familieoberhoupt.

'After all I am the head of this family.'
14 Daughter: (changing the topic) auso Ma, wohere göt dir ize id Landschueuwuche?

'So Mom, where will you now be going for the school camp?'

In this extract, the mother and the son quarrel about the fact that the son's girlfriend does not join the family for meals - a behavior which the mother describes as impolite (7). She also argues that it is really the son who tells his girlfriend to stay away and that it is not Rahel's own wish $(3,5)$. The son clearly does not wish to discuss this issue (6). When the quarrel between mother and son gets louder and louder, the father interrupts them in an even louder voice by asking his wife and son to change the topic (8). In addition, he complains that the two of them are always quarrelling during dinner. This intervention does not go down well with mother and son, as can be seen from the fact that they immediately turn against the father - now as a joint team. It is the daughter who answers the aggressive question posed by the mother in line 11 in an ironic way. ${ }^{18}$ This tone is taken up by the father, and after that the daughter takes the opportunity to successfully change the topic entirely.

There are several comments to be made here on relational work and perceptions of relational work. With respect to frames, i.e., structures of expectations, the mother states that she considers Rahel's staying away from the dinner table to be a breach of norms. She clearly expects her son's girlfriend to spend more time with the family and not to "hide". The metacomment 'impolite' thus refers to behavior that was already witnessed earlier as well as at the time of the interaction, and is now made in the absence of Rahel. Another set of expectations that we see evidence of in this extract is the father's comment on the repeated quarrels between his wife and his son (8). He voices his wish that there should be less schtürme, a Bernese expression describing quarrelling and fighting, derived from 'storm', during dinner time. Finally, there seems to be a clear idea on the part of the mother and her son that their quarrel is theirs rather than one that includes all the members of the family. This can be seen in the content of their immediate reaction to the father's intervention.

Interestingly, there are also several roles and identities explicitly indexed in this brief extract. In lines 5 and 7 the mother creates a sense of the family by using the pronoun $\ddot{s} /$ /us' ('You know, she might want to get to know us, too.'/'hides from us'). This implies that Rahel is not part of this 'us' (yet). While the mother creates a sense of family including her son, she also creates another group consisting of her son and his girlfriend Rahel. In line 3, the mother puts the blame for Rahel's behaviour on her son's rather than on Rahel's shoulders ('No, it was you who said that. Rahel in fact wanted to, I saw it.'). She confirms this criticism in line 5 ('She would never act this stupidly, you are the one who acts stupidly.') This is clearly face-aggravating for the son, but saves the girlfriend's face in that direct criticism of her is avoided. 
From lines 8 to 13 , repeated below from extract (2), the role of the father is under attack:

(3) 8 Father: (very loud) 'Could you now please talk about something else. How can you always be fighting during dinner.'

9 Mother: (aggressive) 'Ahh now you even want to tell us what we're supposed to talk about.'

10 Son: (to Father) 'Mind your own business.'

11 Mother: (to Father) 'Who do you think you are anyway?'

12 Daughter: 'He's God.'

13 Father: (in a rather joking way) 'After all $\mathrm{I}$ am the head of this family.'

14 Daughter: (changing the topic) 'So Mom, where are you now going to go for the school camp?'

Once the father has interrupted his wife and his son's quarrel, he is immediately challenged by them for not having the right to do so $(9,10)$. In line 11 , the mother explicitly and aggressively asks the father about his role ("Who do you think you are anyway?'). According to the daughter, who recorded the conversation and commented on it at a later stage when discussing the analysis with me, she wanted to help her father by saying 'He's God'. Her father takes up this ironic mood and evokes the image of patriarch or head of the family.

The face issues in this brief extract are delicate. The attack on the son's face has already been mentioned (lines 3 and 5). The father's face is clearly chal lenged once his role in the interaction is so bluntly questioned by his wife and son, who were antagonists only seconds before and are now teaming up against him. The daughter finally manages to steer the conversation into calmer waters by means of irony and thus prevents further rounds of aggravating behavior that might have followed if any of the other interactants had tried to answer the aggressive question in line 11. By referring to her mother's occupation in line 14, the daughter highlights her mother's professional face and shifts the attention away from face sensitivities in the family context.

Baumann et al. (2006) stress that the face-threatening acts witnessed in example (2) are in fact not perceived by the participants to be as severe as they might look to analysts not familiar with this particular family and their discursive practice. The conversation indeed proceeded on a neutral tone after the short episode described and did not have any long-term repercussions.

In contrast, extract (4), also taken from Baumann et al. (2006), might look quite unspectacular with respect to the linguistic strategies used, but was experienced as problematic by the daughter with respect to face issues. The episode took place between a father and daughter while preparing the salad for dinner:
(4) 1 Daughter: Söui die Zibele mit däm Häcksler da schnide? 'Shall I cut the onions with that chopper'

2. Father: Ja, das chasch scho. "Yes, you can do that.

(Father observes Daughter who is obviously struggling with assembling the cutting utensil.)

3 Father: Nimm doch eifach es Mässer, das geit of

'Why don't you simply take a knife. That would do the trick too!'

4 Daugther: (rather peevishly and aggressively) Aber weni mit däm wot schnide?!

'But what if I want to cut with this one?!'

5 Father: Ja, de isch scho guet!

'Yes, all right, go ahead.'

The daughter reports that her father's comment to exchange the fancy chopper for a simple knife (3) was taken as a face-threatening criticism of and a challenge to her expertise and competence. This resulted in her snapping at her father in an aggressive way. Her father's reaction, however, points to the possibility that he merely wanted to give advice since he does not react negatively to the challenge in his daughter's response. Instead he takes her comment literally and supports her in her choice of a chopper. Baumann et al. (2006) point out that the extent of the face-threatening character in this brief extract can only be fully explained once it is known that there had been tensions building up between the father and daughter over quite some time (cf. Bucholtz and Hall's positionality principle (b), explained in Section 3).

With respect to the terms politeness or impoliteness, it seems clear that they refer to the way in which interactants deal with each other, either linguistically or more generally. Judgments on politeness and impoliteness are, in other words, metacomments made by social interactants on each other's relational behavior. It may be desirable to be perceived as having the qualities attributed above to one's identity (polite, elegant, cultured, well-mannered, etc.) (Mis)management of relational work that leads to negative perceptions of relational work and intentionally face-aggravating behavior will equally reflect on the product of an interactant's construction of identity in an ongoing emergent network. This is, finally, the link that we can draw between face, face-threatening acts, and identity construction: since there is no faceless communication, interactants are constantly negotiating face needs and are trying to deal with facethreatening acts in ways that serve their current interactional goals; ${ }^{19}$ since face can be understood as a particular mask or role that an interactant wants to have confirmed in social practice, we are automatically dealing with identity construction. To be perceived as polite may then just be one of the many possible at- 
tributes that an interactant wishes to display and hopes to have accepted as part of his or her identity.

\subsection{Relational work and rapport management}

The final theoretical approach to be discussed here in the light of the construction of identity and politeness is Spencer-Oatey's $(2000,2005)$ theory of rapport management, which was developed in research in the field of cross-cultural sociolinguistics. Her framework is discussed here because it shows some useful overlap with the discursive approach to politeness, but also adds further important insights. Spencer-Oatey's (2005) definition of rapport management is similar to the definition of relational work:

Rapport refers to the relative harmony and smoothness of relations between people, and rapport management refers to the management (or mismanagement) of relations between people (SpencerwOatey 2005: 96; author's emphasis).

Spencer-Oatey (2007b: 647) argues that rapport management should be seen as a more general concept than relational work. I hope to demonstrate in this chapter that dealing with "relational" issues is not reductionist. In fact, I would like to suggest that what Spencer-Oatey defines as rapport management is equal to our understanding of relational work (Locher and Watts 2005). It is important to stress that rapport management, just like relational work, includes not only the negotiation of harmonious relations. Spencer-Oatey (2005) mentions four general types of rapport orientations:

a rapport-enhancement orientation (a desire to strengthen or enhance harmonious relations between the interlocutors), a rapport-maintenance orientation (a desire to maintain or protect harmonious relations), a rapport-neglect orientation (a lack of concern or interest in the quality of relations, perhaps because of a focus on self), a rapport-challenge orientation (a desire to challenge or impaix harmonious relations) (Spencer-Oatey 2005: 96; emphasis mine).

Spencer-Oatey's (2005: 97) definition of "(im)politeness" is in line with Watts (2003), Locher (2004), and Locher and Watts (2005) in that she takes "(im)pom liteness to be the subjective judgments that people make about the social appropriateness of verbal and non-verbal behaviour." However, she does use the term (im)politeness as an umbrella term for all kinds of lexemes that index evaluative meanings with positive, negative or neutral connotations, rather than treat it as one of the metacomments.

What is of particular interest to us is that Spencer-Oatey is especially concerned with the perceptions and judgments of rapport management. She proposes that there are three key elements at the basis of such judgments: "behavioural expectations, face sensitivities and interactional wants" (Spencer-Oatey 2005: 96). The behavioral expectations can be linked to the notion of frame pre- viously discussed and stem from the interactants' beliefs about "what is prescribed, what is permitted and what is proscribed" in a particular social practice (2005: 97).20 Spencer-Oatey uses two different concepts of face to describe face sensitivities. The first type is called respectability face and is claimed to be "pan-situational" in that it reflects the interactants' prestige, honor, or good name (based on Ho 1976). Identity face, in contrast, is defined as "situation-specific" and highly vulnerable (based on Goffman 1967). I suggest that we can link these two types of face to the notion of latent and emergent networks previously mentioned: respectability face can be argued to be related to the prestige that a person has established in previous encounters or that are given to him or her in relation to the norms and values of the particular social practice in a first encounter. Respectability face thus refers to the latent links in a social network which are closely related to the frame of that particular social practice. These links, however, will be negotiated in an emergent network, in which a person's identity is constructed and his or her face is most yulnerable. The notion of identity face is thus best linked to the emergent network. In her discussion of examples, Spencer-Oatey (2005) concentrates mainly on identity face, by linking the linguistic analysis with work on self-aspects and positive social values carried out in the field of social psychology (Schwartz 1992; Schwartz et al. 2001). Such self-aspects can be linked to physical features, roles, abilities, tastes, attitudes, etc. (Simon 2004). Spencer-Oatey (2005: 104) maintains that "people's claims to identity face are based on the positive social values that they associate with their various self-aspects" and that people develop "sensitivities" around them. The third element that Spencer-Oatey identifies as contributing to judgments on rapport management is interactional goals or "wants". She makes a distinction between transactional and interactional goals, similar to the argument presented in Section 2.

While Spencer-Oatey stresses that all three elements influence judgments on rapport management, she claims that interactants make judgments on (im)politeness mainly in relation to behavioral expectations. The other two notions (face sensitivities and interactional wants) interact with these expectations, but are seen to be at the base of judgments on rapport management more generally. Her overall argument is that

[a]s people interact with each other, they make dynamic judgments as to whether their rapport has been enhanced, maintained or damaged $[\ldots]$. These judgments (conscious or otherwise) are based to a large extent on assessments of the three key bases of perceptions of rapport: interactional wants, face sensitivities, and behavioural expectations (Spencer-Oatey 2005: 116).

These bases of the dynamic perceptions of rapport are visualized in Figure 2, reproduced from Spencer-Oatey (2005: 116). What is particularly useful for the present discussion is the mention of emotional reactions in the right hand bot- 
tom corner. The discursive approach to the study of politeness and impoliteness claims that interactants make judgments about the appropriateness of behavior in relation to the social norms and expectations of a particular social practice, and that negatively and positively marked evaluations will lead to metacomments such as, for example, polite or impolite. Spencer-Oatey's figure not only visualizes some of the emotions that are evoked by using the term negatively marked or positively marked, but she also convincingly points out that these reactions are dynamic, based on the perception of self and other and are triggered by different interrelated processes.

How can we link these observations to the ideas on identity construction presented in the previous sections? In Spencer-Oatey's (2005) framework, the notion of identity appears most prominently in her discussion of the concept identity face. ${ }^{21}$ The process of constructing identity in interaction, however, is clearly entailed in all three elements of behavioral expectations, face sensitivities, and interactional wants. The notion of role, for example, can be argued to be of importance in all three realms. This claim is discussed with the help of a constructed example, which is based on the author's own cultural expectations:

(5) Imagine that you are a boss who has to bring the bad news to an employee that he has to be laid off because of financial cuts. You know that the employee in question will be upset and unhappy about that decision and will probably contest it. You are also not happy about having to make this person redundant, whose work you have always valued. Nevertheless, you see no other solution but to go ahead with the dismissal. With respect to your role as boss, the following issues may appear important for the conversation in which you tell your employee the bad news:

- Behavioral expectations: As the boss, it is one of your duties to hire employees and make them redundant. You have gone through similar situations before and you can draw on this particular frame here. For example, you plan to invite the employee to your office, you will give him the bad news in a factual way; you will give reasons for the dismissal, and you will offer understanding for the difficult situation that you put your employee in. You will make sure that you fulfil all the legal requirements that may be attached to this activity. From the employee you expect that he recognizes the particular type of interaction and that he orients to it by reacting in a factual rather than an emotional way.

- Interactional wants: Your interactional goal is to conduct a factual and efficient conversation. Your interpersonal goal is to be able to conclude the conversation on such a note that your role as boss is not challenged, while you are willing to enhance the employee's face, circumstances allowing, by ac-

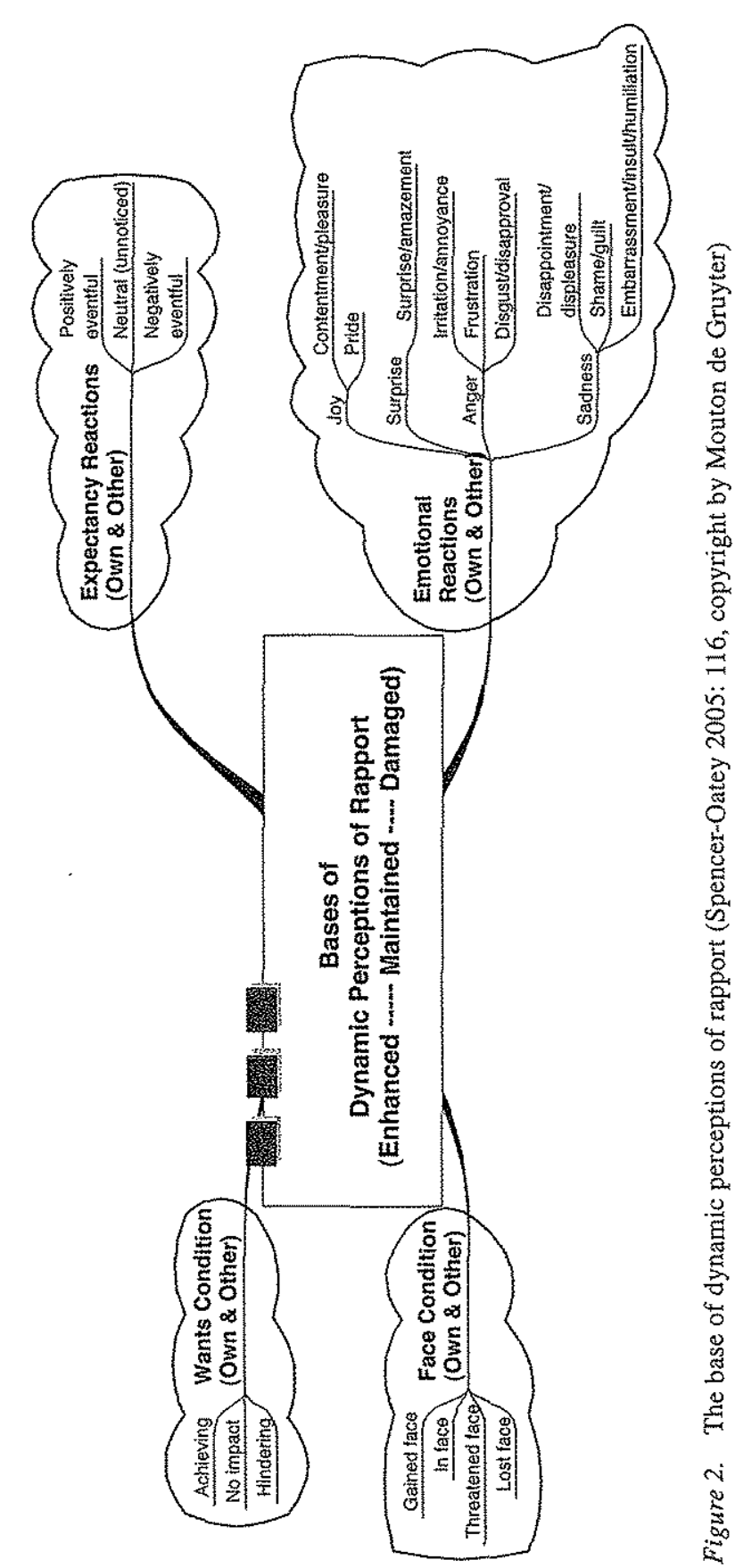


knowledging the employee's difficult situation as a result of terminating the work relations.

- Face sensitivities: You are sensitive to any challenge of your role as boss (appearing in control, being legitimized to take decisions, etc.) that might come from the upset employee, while you are aware of the face-threatening character of the act of making somebody redundant.

This constructed scenario is admittedly far from accounting for the complexities of real interaction. It has shown, however, that the three elements that SpencerOatey identifies are indeed closely related and together will contribute to the identity construction that will be the product of the orientations to these three elements once the interaction takes place.

It has to be stressed that Spencer-Oatey deals with the question of judgments on rapport management in her (2005) paper and explicitly mentions that she is not concerned with "how (im)politeness, face and/or rapport are dynamically managed in interaction" (96). I take this to mean that such a focus is still possible, but not the subject of the paper. The scenario described above was formulated in such a way that it outlined relational concerns at the outset of the interaction. It was meant to illustrate that the three elements that Spencer-Oatey describes as being at the basis of judgments of rapport management will also be crucial in identity construction in general.

\section{Concluding remarks}

The aim of this chapter was to link work on the construction of identity in interaction with work on linguistic politeness in order to point out synergies in the two research fields. The recent literature on identity construction has been reviewed with a brief excursion into the issue of language and gender. The literature on politeness was represented by two seminal research traditions, one inspired by Brown and Levinson $(1978,1987)$, and the other by Leech (1983). In addition, the more recent discursive approach to politeness issues was introduced to indicate new developments in this field of research (Locher and Watts 2005). These approaches were discussed in connection with the construction of identity.

I hope to have demonstrated that the view which considers identity as emerging in interaction and the discursive approach to politeness with its focus on relational work can more generally be fruitfully combined in linguistic research which explores interpersonal communication. The overlap in the approaches can be located in the position that there is no communication without a relational aspect, and that "identity is inherently relational" (Bucholtz and Hall 2005: 605). In addition, the understanding of politeness as one of many evaluative concepts, the contents of which are discursively negotiated in social practices over time, highlights the importance of practice or agency that is also crucial to the current postmodernist understanding of identity. The Goffmanian conceptualization of the metaphor face, being central to politeness research, can also be of use for identity research if it is taken to mean a "role" or "mask" that is being negotiated in an emergent network rather than a predefined set of wants.

Finally, the terms relational work, facework, identity work, and rapport management have been shown to refer to the same phenomenon -- the negotiation of relations and identities in interaction, while a particular face or identity is the product of this work. It remains to be emphasized quite clearly that much more empirical research is needed to understand the intricacies of relational work in all its facets. This chapter is meant to encourage such research.

\section{Notes}

1. The author wishes to thank Anne-Françoise Baer-Boesch, Lea Baumann, Derek Bousfield, Nicole Nyffenegger, Lukas Rosenberger, Philipp Schweighauser, and Ariane Studer for their perceptive and critical feedback on early drafts of this chapter, and Gerd Antos, Eija Ventola, Tilo Weber and Richard J. Watts for their comments on the final version of this text. A particular thank you goes to my students Lea Baumann, Manuela Burgermeister, Sonaljeet Kundan and Ariane Studer for sharing their data with me.

2. Swann (2000) reviews several authors who combine gender with politeness issues, among them Brown (1980), Lakoff (1975), and Holmes (1995). However, these studies are not oriented to the same degree to the construction of identity and the role that politeness plays in this process as the present chapter is. More recent work (e.g., Mullany 2004) combines a constructivist approach to gender with politeness research.

3. For a detailed discussion of different approaches to style and register in language, see Eckert and Rickford (2001).

4. Other researchers speak of a tri-partite distinction: the ideational (expressing content), the textual (organizing information into texts), and the interpersonal (Kresta 1993: 32, who bases his approach on Halliday 1976, 1981). The first two are included in the focus on content (transactional) while the latter corresponds to the relational aspect of an utterance (interactional).

5. The term facework is often used by researchers who follow Brown and Levinson's (1987) politeness theory. It has been largely reserved to describe only appropriate and polite behavior with a focus on face-threat mitigation. To avoid confusion and in favor of clarity, the term relational work is adopted to highlight that the negotiation of the relational aspect of language does not only involve mitigating strategies.

6. In her paper "Yes, but is it gender?", Swann (2002) points out the importance of methodological and theoretical considerations when studying gender. One of her many critical comments is that it cannot be enough to study only women in interaction to claim that we are witnessing women's talk, since we first have to find out how much of this women's talk overlaps with men's talk to make such a claim. 
7. The notion of face has been reproached for being culturally bound and based too much on the individual (Gu 1990: 241-242; Matsumoto 1988: 405). While I agree that the metaphor of face is clearly culturally bound, I claim that the theoretical notion of face as described in this section is not.

8. The metaphor of the stage is evoked here where people can put on different masks or faces. However, $I$ do not wish to imply that a person can take off such a mask to reveal an underlying 'true' identity, since there is no face-less communication (cf. Tracy 1990: 221; Scollon and Scollon 2001: 48).

9. See the discussion of face as used by Brown and Levinson (1987) in Section 4.2.

10. Cf. note 5 .

11. See also Ruhi (2007) for a recent discussion and development of the concept face.

12. I refer the reader to Werkhofer (1992), Eelen (2001), Watts (2003), and Locher (2004) for critical reviews of Brown and Levinson's (1978/1987) work.

13. I do not mean to claim that all American students share the same expectations with respect to the use of address terms. The point is that the social practice in question had different norms with respect to the use of address terms than that of the two individuals in question.

14. This comment refers in fact to a complex set of transgressions that are further discussed in Grice (1975).

15. For the concept of community of practice, consult Eckert and McConnell-Ginet (1992a/b), Wenger (1998), and Meyerhoff (2002).

16. Other studies on the historical concept of politeness in the field of sociohistorical linguistics are Fitzmaurice (1998) and Watts $(1999,2002)$.

17. The transcript in Swiss German was produced by the daughter and mother in the example; the English translation is mine.

18. Here the "Father knows best" ideology, studied by Ochs and Taylor (2001), is evoked in an ironic fashion.

19. I do not wish to imply that this interaction always has to be conscious. See Locher and Watts (2008) for further comments on intentionality.

20. Spencer-Oatey (2005: 98-100) describes different aspects that are part of behavioral expectations: contract/legal agreements and requirements, explicit/implicit role specifications, the interactional principles of equity and association, and behavioral conventions, norms and protocols.

21. In Spencer-Oatey (2007b: 642-644), the author discusses the link between the concept of face and identity explicitly by claiming that the two concepts should be kept apart. However, I argue that we can gain much by equating face with identity, as outlined in this chapter.

\section{References}

Adelswärd, Viveka and Claes Nilholm

2000 Who is Cindy? Aspects of identity work in a teacher-parent-pupil talk at a special school. Text 20(4): 545-568.

Baumann, Lea, Manuela Burgermeister, Sonaljeet Kundan and Ariane Studer

2006 It really depends on the family: Responses to impoliteness among friends and family members. Unpublished paper, Department of English Languages and Literatures, University of Berne.
Bousfield, Derek and Miriam A. Locher (eds.)

2008 Impoliteness in Language. Studies on its Interplay with Power in Theory and Practice. Berlin/New York: Mouton de Gruyter.

Brown, Penelope

1980 How and why are women more polite: Some evidence from a Mayan community. In: Sally McConnell-Ginet, Ruth Borker and Nellie Furman (eds.) Women and Language in Literature and Society, 111-136. New York: Praeger.

Brown, Penelope and Stephen C. Levinson

1978 Universals in language usage. Politeness phenomena. In: Esther N. Goody (ed.), Questions and Politeness, 56-289. Cambridge: Cambridge University Press.

Brown, Penelope and Stephen C. Levinson

1987 Politeness: Some Universals in Language Usage. Cambridge: Cambridge University Press.

Brown, Roger and Albert Gilman

1960 The pronouns of power and solidarity. In: Thomas Sebeok (ed.), Style in Language, 253-276. Cambridge: Massachusetts Institut of Technology Press.

Bucholtz, Mary

2004 Language, gender, and sexuality. In: Edward Finegan and John Rickford (eds.), Language in the USA: Themes for the Twenty-first Century, 411-427. New York: Cambridge University Press.

Bucholtz, Mary and Kira Hall

2005 Identity and interaction: A sociocultural linguistic approach. Discourse Studies 7(4-5): 585-614.

Culpeper, Jonathan

1996 Towards an Anatomy of Impoliteness. Journal of Pragmatics 25(3): 349-367.

Culpeper, Jonathan

2005 Impoliteness and 'The weakest link'. Journal of Politeness Research 1(1): 35-72.

Culpeper, Jonathan, Derek Bousfield and Anne Wichmann

2003 Impoliteness revisited: With special reference to dynamic and prosodic aspects. Journal of Pragmatics 35,10-11: 1545-1579.

Davies, Bronwyn and Rom Harré

1990 Positioning: The social construction of self. Journal for the Theory of Social Behavior 20: 43-63.

De Fina, Anna

2003 Identity in Narrative: A Study of Immigrant Discourse. Amsterdam: Benjamins.

Durkheim, Emile

1915 The Elementary Forms of the Religious Life. London: G. Allen \& Unwin.

Eckert, Penelope and Sally McConnell-Ginet

1992a Communities of practice: Where language, gender, and power all live. In: Kira Hall, Mary Bucholtz and Birch Moonwomon (eds.), Locating Power: Proceedings of the Second Berkeley Women and Language Conference, 89-99. Berkeley, CA: Women and Language Group. 
Eckert, Penelope and Sally McConnell-Ginet

1992b Think practically and act locally: Language and gender as communitybased practice. Annual Review of Anthropology 21: 461-490.

Eckert, Penelope and John R. Rickford (eds.)

2001 Style and Sociolinguistic Variation. Cambridge: Cambridge University Press. Eelen, Gino

2001 A Critique of Politeness Theories. Manchester: St. Jerome Publishing.

Fill, Alwin

1990 Scherz und Streit aus ethnolinguistischer Sicht. Papiere zur Linguistik 43(2): $117-125$.

Fitzmaurice, Susan

1998 The commerce of language in the pursuit of politeness in eighteenth-cen-

Fraser, Bruce tury England. English Studies 78: 309-328.

1990 Perspectives on politeness. Journal of Pragmatics 14(2): 219-236.

Goffman, Erving (ed.)

1967 Interaction Ritual: Essays on Face-to-Face Behavior. Garden City, NY: Anchor Books.

Graham, Sage Lambert

2007 Disagreeing to agree: Conflict, (im)politeness and identity in a computermediated community. Joumal of Pragmatics 39(4): 742-759.

Graham, Sage Lambert

2008 A manual for (im)politeness? The impact of the FAQ in electronic communities of practice. In: Derek Bousfield and Miriam A. Locher (eds.), Impoliteness in Language. Studies on its Interplay with Power in Theory and Practice, 281-304. Berlin/New York: Mouton de Gruyter.

Grice, H. Paul

1975 Logic and conversation. In: Peter Cole and Jerry L. Morgan (eds.), Syntax and Semantics, Volume 3, Speech Acts, 41-58. New York: Academic Press.

Gu, Yuego

1990 Politeness phenomena in modern Chinese. Journal of Pragmatics 14: $237-257$.

Halliday, Michael A. K.

1976 System and Function in Language. London: Oxford University Press.

Halliday, Michael A. K.

1981 Linguistic function and literary style: An inquiry into the language of William Golding's 'The Inheritors'. In: Donald C. Freeman (ed.), Essays in Modern Stylistics, 325-361. London: Methuen.

Held, Gudrun

1995 Verbale Höflichkeit. Studien zur linguistischen Theoriebildung und empirische Untersuchung zum Sprachverhalten französischer und italienischer Jugendlicher in Bitt- und Dankessituationen. Tübingen: Narr.

Ho, Davis Yao-Fai

1976 On the concept of face. American Journal of Sociology 81(4): 867-884.

Holmes, Janet

1995 Women, Men and Politeness. New York: Longman.
Joseph, John Earl

2004 Language and ldentity: National, Ethnic, Religious. Basingstoke: Palgrave Macmillan.

Kasper, Gabriele

1990 Linguistic politeness: Current research issues. Journal of Pragmatics 14(2): 193-218.

Kienpointner, Manfred

1997 Varieties of rudeness: Types and functions of impolite utterances. Functions of Language $4(2): 251-287$

Kresta, Ronald

1993 Interpersonality and linguistic politeness in English and German linguistic texts. Papiere zur Linguistik 48(1): $29-46$

Lachenicht, Lance $G$.

1980 Aggravating language: A study of abusive and insulting language. Papers in Linguistics. International Joumal in Human Communication 13(4): 607-687.

Lakoff, Robin

1975 Language and Woman's Place. New York: Harper and Row.

Leech, Geoffrey N.

1983 Principles of Pragmatics. New York: Longman.

Locher, Miriam A.

2004 Power and Politeness in Action: Disagreements in Oral Communication. Berlin/New York: Mouton de Gruyter.

Locher, Miriam A.

2006a Advice Online: Advice-giving in an American Internet Health Column. Amsterdam: Benjamins.

Locher, Miriam A.

$2006 \mathrm{~b}$ Polite behavior within relational work: The discursive approach to politeness. Multilingua 25(3): 249-267.

Locher, Miriam A. and Derek Bousfield

2008 Introduction: Impoliteness and power in language. In: Derek Bousfield and Miriam A. Locher (eds.), Impoliteness in Language. Studies on its Interplay with Power in Theory and Practice, 1-13. Berlin/New York: Mouton de Gruyter.

Locher, Miriam A. and Sebastian Hoffmann

2006 The emergence of the identity of a fictional expert advice-giver in an American internet advice column. Text and Talk 26(1): 67-104.

Locher, Miriam A. and Richard J. Watts

2005 Politeness theory and relational work. Journal of Politeness Research 1,1: $9-33$.

Locher, Miriam A. and Richard J. Watts

2008 Relational work and impoliteness: Negotiating norms of linguistic behaviour. In: Derek Bousfield and Miriam A. Locher (eds.), Impoliteness in Language. Studies on its Interplay with Power in Theory and Practice, 77-99. Berlin/New York: Mouton de Gruyter.

Matsumoto, Yoshiko

1988 Reexamination of the universality of face: Politeness phenomena in Japanese. Journal of Pragmatics 12(4): 403m-426. 


\section{Mendoza-Denton, Norma}

2002 Language and identity. In: J. K. Chambers, Peter Trudgill and Natalie Schil. ling-Estes (eds.), Handbook of Language Variation and Change, 475-499. Oxford: Blackwell.

\section{Meyerhoff, Miriam}

2002 Cornmunities of practice. In: J. K. Chambers, Peter Trudgill and Natalie Schilling-Estes (eds.), Handbook of Language Variation and Change, 526-548. Oxford: Blackwell.

Mills, Sara

2002 Rethinking politeness, impoliteness and gender identity. In: Lia Litosseliti and Jane Sunderland (eds.), Gender Identity and Discourse Analysis, 69-89. Amsterdam: Benjamins.

Mills, Sara

2003 Gender and Politeness. Cambridge: Cambridge University Press.

Mills, Sara

2004

Mills, Sara

2005 Gender and impoliteness. Journal of Politeness Research 1(2): 263-280.

Mullany, Louise

2004 Gender, politeness and institutional power roles: Humour as a tactic to gain compliance in workplace business meetings. Multilingua 23(1-2): $13-37$.

Mullany, Louise

2008 'Stop hassling me!' Impoliteness, power and gender identity in the professional workplace. In: Derek Bousfield and Mirian A. Locher (eds.), Impoliteness in Language. Studies on its Interplay with Power in Theory and Practice, 231-251. Berlin/New York: Mouton de Gruyter.

Ochs, Elinor and Carolyn Taylor

2001 The "Father knows best" dynamic in dinnertime narratives. In: Alessandro Duranti (ed.), Linguistic Anthropology. A Reader, 431-449. Oxford: Blackwell.

O'Driscoll, Jim

1996 About face: A defence and elaboration of universal dualism. Joumal of Pragmatics 25(1): 1-32.

Ruhi, Şükriye and Hale Işık-Güler

2007 Conceptualizing face and relational work in (im)politeness: Revelations from politeness lexemes and idioms in Turkish. Joumal of Pragmatics 39(4): 681-711.

Schiffrin, Deborah

1996 Narrative as self-portrait: Sociolinguistic constructions of identity, Language in Society 25(2): 167-203.

Schnurr, Stephanie, Meredith Marra and Janet Holmes

2007 Being (im)polite in New Zealand workplaces: Maori and Pakhea leaders. Journal of Pragmatics 39(4): 712-729.

Schnurr, Stephanie, Meredith Marra and Janet Holmes

2008 Impoliteness as a means of contesting power relations in the workplace. In: Derek Bousfield and Miriam A. Locher (eds.), Impoliteness in Language.
Studies on its Interplay with Power in Theory and Practice, 211-229. Berlin/New York: Mouton de Gruyter.

Schwartz, Shalom

1992 Universals in the content and structure of values: Theoretical advances and empirical tests in 20 countries. In: Mark P. Zanna (ed.), Advances in Experimental Social Psychology, 1-65. San Diego: Academic Press.

Schwartz, Shalom, Gila Melech, Arielle Lehmann, Steven Burgess, Mari Harris and Vicki Owens

2001 Extending the cross-cultural validity of the theory of human values with a different method of measurement. Journal of Cross Cultural Psychology $32(5): 519-542$.

Scollon, Ron and Suzanne W. Scollon

2001 Intercultural Communication: A Discourse Approach. $2^{\text {nd }}$ edition. Oxford: Blackwell.

Simon, Bernd

2004 Identity in Modern Society: A Social Psychological Perspective. Oxford: Blackwell.

Spencer-Oatey, Helen

2000 Rapport management: A framework for analysis. In: Helen Spencer Oatey (ed.), Culturally Speaking: Managing Rapport through Talk across Cul tures, 11-46. London: Continuum.

Spencer-Oatey, Helen

2005 (Im)Politeness, face and perceptions of rapport: Unpackaging their bases and interrelationships. Journal of Politeness Research 1(1): 95-119.

Spencer-Oatey, Helen

2007a Identity, face and (im)politeness. Journal of Pragmatics 39(4): 635638.

Spencer-Oatey, Helen

$2007 \mathrm{~b}$ Theories of identity and the analysis of face. Journal of Pragmatics 39(4): $639-656$.

Stein, Dieter

1994 Sorting out the variants: Standardization and social factors in the English language 1600-1800. In: Dieter Stein and Ingrid Tieken-Boon van Ostade (eds.), Towards a Standard English 1600-1800, 1-17. Berlin/New York: Mouton de Gruyter.

Swann, Joan

2000 Gender and language use. In: Rajend Mesthrie, Joan Swann, Andrea Deumert and William L. Leap (eds.), Introducing Sociolinguistics, 316-353. Edinburgh: Edinburgh University Press.

Swann, Joan

2002 Yes, but is it gender? In: Lia Litosseliti and Jane Sunderland (eds.), Gender Identity and Discourse Analysis, 43-67. Amsterdam: Benjamins.

\section{Tannen, Deborah}

1993 What's in a frame? Surface evidence for underlying expectations. In: Deborah Tannen (ed.), Framing in Discourse, 14-56. Oxford: Oxford University Press. 
The Oxford English Dictionary

$19892^{\text {nd }}$ edition. Oxford: Oxford University Press.

Tracy, Karen

1990 The many faces of facework. In: Howard Giles and Peter Robinson (eds.), Handbook of Language and Social Psychology, 209-226. Chichester: Wiley.

Watts, Richard J.

1989 Relevance and relational work: Linguistic politeness as politic behavior. Multilingua 8(2-3): 131-166.

Watts, Richard J.

1991 Power in Family Discourse. Berlin/New York: Mouton de Gruyter

Watts, Richard J.

1992 Linguistic politeness and politic verbal behaviour: Reconsidering claims for universality. In: Richard I. Watts, Sachiko Ide and Konrad Ehlich (eds.) Politeness in Language: Studies in its History, Theory and Practice, 43-69. Berlin/New York: Mouton de Gruyter.

Watts, Richard J.

1999 Language and politeness in early eighteenth century Britain. Pragmatics $9(1): 5-20$

Watts, Richard J.

2002 From polite language to educated language: The re-emergence of an ideology. In: Richard J. Watts and Peter Trudgill (eds.), Alternative Histories of English, 155-172. London: Routledge.

Watts, Richard J.

2003 Politeness. Cambridge: Cambridge University Press.

Watts, Richard J

2005 Linguistic politeness research: Quo vadis? In: Richard J. Watts, Sachiko Ide and Konrad Ehlich (eds.), Politeness in Language: Studies in its History, Theory and Practice, $2^{\text {nd }}$ Tevised and expanded edition, xi-xlvii. Berlin/ New York: Mouton de Gruyter.

Watts, Richard J., Sachiko Ide and Konrad Ehlich

1992 Introduction. In: Richard J. Watts, Sachiko Ide and Konrad Ehlich (eds.), Politeness in Language: Studies in its History, Theory and Practice, 1-17. Berlin/New York: Mouton de Gruyter.

Watzlawick, Paul, Janet Helmick Beavin and Don D. Jackson

1967 Pragmatics of Human Communication: A Study of Interactional Patterns, Pathologies and Paradoxes. New York: Norton.

Wenger, Etienne

1998 Communities of Practice: Learning, Meaning, and Identity. Cambridge: Cambridge University Press.

Werkhofer, Konrad T.

1992 Traditional and modern views: The social constitution and the power of politeness. In: Richard J. Watts, Sachiko Ide and Konrad Ehlich (eds.), Polite ness in Language: Studies in its History, Theory and Practice, 155-197. Berlin/New York: Mouton de Gruyter.

\section{Humor, jokes, and irony versus mocking, gossip, and black humor}

\section{Alexander Brock}

\section{Introduction}

Humor, jokes, irony, mocking, gossip and black humor are labels for a group of communicative activities which are related and yet sufficiently different to earn themselves specific terms. Many other similar ones could be added, including sarcasm, teasing, banter and rumor. People often make funny remarks, they are ironic or sarcastic, but most of us find it hard to tell exactly what, for instance, the difference between humor and irony is and what specific contribution they make to the ongoing conversation. The term "versus" in the title, moreover, suggests a kind of opposition between some of the categories. Maybe this has to do with the way society commonly evaluates them, crudely speaking: "Humor and irony are good, whereas gossip and mocking are bad." At a closer look, however, things are far less straightforward. The difficulty of defining these categories and analyzing them in context becomes palpable as soon as one looks at a seemingly simple example, like the following. Example (1) shows an extract from a conversation among two 17-year-old school-boys who are strolling around town. Both are relaxed and a little bored:

(1) Holiday Job

Utz:2 Ich arbeite vielleicht im Sommer in den ersten paar Wochen in der I work maybe in summer in the first few weeks at the "Taverne".

"Tavern".

'I might work at the Tavern in the first few weeks of the summer.'

Fred: Wow, hier in Seblitz? Als was?

"Wow, here in Seblitz? As what?"

Utz: Als äh Besitzer. (Beide lachen)

'As erm proprietor. (both laugh)'

Town 2, 1 May, 2004

It is tempting to describe this exchange as harmless joking, because the jocular remark about a school-boy working as a proprietor serves a simple entertainment function, like so many other cases of conversational joking. If, however, Fred were a notorious show-off, then Utz's remark might be interpreted as an echoic comment on Fred's usual conversational behavior, to be classified as 